\title{
Penilaian Pelaksanaan Kurikulum Mata Pelajaran Sains Rumah Tangga Menggunakan Model Stake Countenance: Satu Kajian Literatur
}

\author{
Nor Asimah Zakaria ${ }^{1,2}$ \\ ${ }^{1}$ Universiti Pendidikan Sultan Idris, Tanjung Malim, Perak 35900 Malaysia \\ ${ }^{2}$ Universiti Sains Malaysia,Pusat Pengajian Ilmu Pendidikan, 11800 Pulau Pinang, Malaysia \\ *Corresponding author, e-mail: zsyimah@ftv.upsi.edu.my
}

\begin{abstract}
The purpose of this concept paper was to discuss and analysis evaluation models using in the curriculum implementation or educational program evaluation. This paper focused on secondary school home science education subject and Stake Countenance Model. This model focused on congruence between what was intended to occur and what was actually observed to occur before, during, and after curriculum implementation. The Stake Countenance Model used antecedents, transactions and outcomes as a core concept to structure the view of the curriculum implementation evaluation or an educational program evaluation. The Stake model demonstrated its effectiveness by facilitating a thorough examination of both quantitative and qualitative research method.
\end{abstract}

Keywords: Model stake countenance, Curriculum, Home science education.

\begin{abstract}
Abstrak
Kertas konsep ini adalah bertujuan untuk membincangkan dan menganalisis model penilaian yang digunakan dalam penilaian pelaksanaan kurikulum atau program pendidikan. Kertas konsep ini memberi tumpuan kepada Mata Pelajaran Sains Rumah Tangga sekolah menengah yang diajar pada peringkat menengah atas dan Model Stake Countenance. Model ini membincangkan dua matrik iaitu matrik deskripsi dan matrik pertimbangan yang memberi tumpuan kepada kepada kesesuaian antara apakah yang dirancang untuk berlaku dan apakah yang sebenarnya berlaku semasa perlaksanaan dengan melakukan pemerhatian sebelum, semasa, dan selepas pelaksanaan sesuatu kurikulum atau program pendidikan. Model Stake Countenance membincangkan tiga fasa pengumpulan data; masukan, proses dan hasil sebagai teras konsep dalam penilaian pelaksanaan kurikulum atau penilaian program pendidikan. Model Stake menunjukkan keberkesanannya dengan memudahkan penilai membuat pertimbangan menyeluruh dengan menggunakan kaedah penyelidikan kuantitatif atau kualitatif.
\end{abstract}

Kata Kunci: Model Stake Countenance, Kurikulum, Pendidikan Sains Rumah Tangga.

\section{PENGENALAN}

Penilaian adalah satu proses berterusan untuk menentukan kurikulum yang digubal dan dicadang dilaksanakan dalam pengajaran oleh guru. Disamping itu hasil dapatan penilaian dapat memberi bimbingan dan panduan kepada pemegang taruh untuk mengatasi dan memperbaiki kekurangan yang wujud. Kaedah kualitatif dan kuantitatif boleh digunakan dalam pelaksanaan penilaian bagi mendapat maklum balas yang memberi gambaran sebenar dan menyeluruh. Hasil maklum balas kajian boleh diambil perhatian dalam menjalankan kurikulum atau program pendidikan lain pada masa hadapan. Pelbagai teknik penilaian boleh dan pernah digunakan untuk menilai pelaksanaan sesuatu kurikulum. Di antaranya ialah pemerhatian, temu bual pentadbir, guru dan murid serta pihak yang terlibat dalam pelaksanaan sesuatu kurikulum itu.

Penilaian merupakan satu komponen penting dalam semua kurikulum atau program pendidikan bagi mengkaji tujuan program, matlamat dan objektif program serta aktiviti pembelajaran mengikut perancangan yang telah dicadangkan pada awal penggubalan sesuatu kurikulum. Justeru itu, pemilihan model penilaian yang tepat akan memberi 
maklumat yang memyeluruh kepada sesebuah organisasi dalam membuat keputusan. Kertas konsep ini membincangkan model penilaian dalam kurikulum dan program pendidikan.

\section{DEFINISI PENILAIAN}

Tyler (1942) yang dianggap sebagai pelopor dalam bidang penilaian mendefinisikan penilaian sebagai satu proses penentuan pencapaian objektif. Scriven dalam Fitzpatrick, Sanders, \& Worthen (2017) pada awalnya mendefinisikan penilaian sebagai satu proses pertimbangan sesuatu perkara yang dinilai. Manakala Rossi (2018) menyatakan bahawa penilaian adalah satu piawaian atau kriteria yang digunakan untuk menilai prestasi sesuatu perkara yang dinilai dan menawarkan maklumat dalam membuat keputusan. Scriven (1999) menerangkan bahawa penilaian mempunyai dua cabang iaitu pertama, cabang mengumpul data dan kedua cabang bagi menjelaskan serta mengesahkan nilai dan piawaian yang berkenaan. Stufflebeam \& Shinkfield (2012) menjelaskan bahawa penilaian adalah satu proses pengumpulan maklumat yang diperlukan berkaitan dengan sesuatu program atau pelaksanaan sesuatu kurikulum yang dinilai berdasarkan tiga garis panduan yang penting iaitu; (i) menerangkan dengan tepat (delineating information) persoalan kajian yang dinilai, (ii) memperoleh maklumat (obtaining information) yang dinilai dan (iii) menyediakan maklumat (providing information) itu bagi membolehkan keputusan dibuat oleh pihak yang berkaitan dalam sesebuah organisasi.

Manakala Mamat (1996) menjelaskan bahawa penilaian adalah satu proses yang menentukan siapa dan kenapa sesuatu penilaian dilaksanakan. Oleh itu, berdasarkan kepada penjelasan yang dinyatakan penilaian boleh dirumuskan kepada empat definisi utama iaitu, pertama penilaian adalah satu tindakan pentaksiran nilai. Penumpuan lebih kepada nilai, kedua penilaian adalah satu ketetapan sejauh manakah objektif pelaksanaan program atau kurikulum yang dikehendaki telah dicapai dan penumpuannya adalah berfokus kepada pencapaian objektif sesuatu program atau kurikulum yang dilaksanakan, ketiga penilaian adalah satu tindakan memperoleh dan mengumpul maklumat yang berfaedah untuk dijadikan pilihan dalam membuat keputusan dan penumpuannya lebih berfokus kepada menentukan keputusan yang akan dibuat dan akhir sekali, keempat penilaian juga merupakan satu tindakan perbandingan diantara bukti yang sah dengan kriteria atau piawaian yang telah ditetapkan untuk membuat pertimbangan dan penumpuan lebih berfokus kepada pertimbangan. Justeru itu, dapat disimpulkan bahawa makna penilaian adalah berkisar pada tiga persoalan utama, iaitu; (i) Apa -membuat perbandingan hasil iaitu bukti dengan kriteria atau piawaian yang telah ditetapkan pada awal tindakan penilaian dilaksanakan, (ii) Bagaimana - dilaksanakan secara tersusun dan sistematik dan (iii) Kenapa - untuk mendapatkan keputusan dan kesimpulan yang boleh diguna untuk menambah baik sesuatu program pendidikan atau kurikulum pendidikan.

\section{DEFINISI KURIKULUM}

Tyler (1949) mendefinisikan kurikulum sebagai seluruh pengalaman pembelajaran yang dirancang dan diarahkan oleh sekolah berdasarkan empat komponen asas iaitu tujuan pendidikan, proses pembelajaran, organisasi isi kandungan serta bahan pengajaran dan penilaian pembelajaran. Manakala Ornstein \& Hankins (2013) mentakrifkan kurikulum sebagai satu pelan atau rancangan untuk tindakan atau satu dokumen bertulis yang mengandungi strategi untuk mencapai matlamat yang dihajati.

Kurikulum ialah segala rancangan pendidikan iaitu akademik dan kokurikulum yang dikendalikan oleh sesebuah sekolah atau institusi pendidikan untuk mencapai matlamat pendidikan. Ia suatu rancangan yang meliputi segala ilmu pengetahuan, kemahiran, nilai

Zakaria, N. A. (2019). Penilaian Pelaksanaan Kurikulum Mata Pelajaran Sains Rumah Tangga Menggunakan Model Stake Countenance: Satu Kajian Literatur. Journal of Vocational Education Studies, 2(1), 37-46. DOI: https://doi.org/10.12928/joves.v2i1.647. 
dan norma, unsur kebudayaan dan kepercayaan masyarakat untuk diwariskan kepada ahlinya. Kurikulum kebangsaan yang ditetapkan hendaklah menentukan pengetahuan, kemahiran dan nilai yang dijangka akan diperolehi oleh murid pada akhir tempoh persekolahan masing-masing (Akta Pendidikan 1996 (akta 550), 1996).

Menurut Kassim \& Jalal (2015) kurikulum merupakan bentuk penulisan yang dirancang mengandungi senarai topik pembelajaran yang akan dilaksanakan dalam pembelajaran dan semua pengalaman yang berlaku di sekolah. Rohana \& rakan (2017) mentakrifkan kurikulum berdasarkan kepada tiga asas utama iaitu: (i) kurikulum adalah satu rancangan pendidikan yang yang melalui satu proses dan usaha atau kegiatan dalam mencapai sesuatu tujuan, (ii) bagi mencapai tujuan tersebut kegiatan disusun dan diatur (iii) ada pihak atau organisasi yang bertanggungjawab menyusun dan mengatur rancangan pendidikan bagi melaksanakan rancangan tersebut di sesebuah organisasi mengikut acuan yang telah ditetapkan.

\section{MATA PELAJARAN SAINS RUMAH TANGGA}

Pelaksanaan Kurikulum Standard Sekolah Menengah (KSSM) yang bermula secara berperingkat pada tahun 2017 bagi semua sekolah menengah dalam Sistem Pendidikan Kebangsaan seperti yang diperuntukkan mengikut Seksyen 18 di bawah Akta Pendidikan 1996 [Akta 550].

Mata pelajaran Sains Rumah Tangga (SRT) adalah Mata Pelajaran Elektif Ikhtisas (MPEI) dalam kelompok Sains, Teknologi, Kejuruteraan dan Matematik (STEM) untuk menengah atas tingkatan 4 dan 5 dengan peruntukkan masa minimum 160 minit seminggu, 96 jam setahun (Pekeliling Ikhtisas Kementerian Pendidikan Malaysia bilangan 9 Tahun 2016. Pelaksanaan Kurikulum Standard Sekolah Menengah secara berperingkat-peringkat mulai tahun 2017, 2016).

Mata Pelajaran Sains Rumah Tangga merupakan penjenamaan semula bagi mata pelajaran Ekonomi Rumah Tangga (ERT) Tingkatan 4 dan 5 yang telah dilaksanakan mulai tahun 1992. Pendidikan Sains Rumah Tangga menyediakan pengajian dalam empat komponen utamanya iaitu Pengurusan Sumber Keluarga dan Tempat Kediaman, Pakaian dan Jahitan, Makanan dan Pemakanan serta Penyediaan dan Penyajian Makanan (Dokumen Standard Kurikulum dan Pentaksiran, Mata Pelajaran Sains Rumah Tangga Tingkatan 4., 2015).

\section{TUJUAN PENILAIAN KURIKULUM}

Rossi (2018), menyatakan tujuan penilaian adalah untuk memberi jawapan kepada persoalan tentang apa yang dilakukan oleh sesebuah kurikulum atau program pendidikan, bagaimana kurikulum atau program dilaksanakan dan adakah kurikulum atau program tersebut memberi faedah dan bernilai. Menurut Cronbach (1983) fokus utama aktiviti penilaian adalah untuk tujuan penambah baik kursus dan beliau menjelaskan bahawa tiga ketetapan dan keputusan yang boleh dibuat dengan menggunakan dapatan sesuatu penilaian program atau kurikulum ialah; (i) menambah baik program atau kurikulum dengan menentukan bahan pengajaran dan pembelajaran, kaedah pengajaran dan pembelajaran yang sesuai serta menentukan perubahan yang perlu dilakukan bagi mendapatkan hasil yang lebih berkesan, (ii) keputusan tentang murid iaitu mengenal pasti keperluan murid untuk merancang kaedah pengajaran dan pembelajaran, membuat pertimbangan dan mengadili kecemerlangan atau merit bagi tujuan pemilihan, pengkategorian dan penentuan murid (selection and grouping), membiasakan dan melatih murid (acquainting) dengan kemajuan serta kelemahan dan (iii) peraturan pentadbiran

Zakaria, N. A. (2019). Penilaian Pelaksanaan Kurikulum Mata Pelajaran Sains Rumah Tangga Menggunakan Model Stake Countenance: Satu Kajian Literatur. Journal of Vocational Education Studies, 2(1), 37-46. D0I: https://doi.org/10.12928/joves.v2i1.647. 
sesebuah sekolah atau organisasi iaitu dengan mengadili sejauh mana berkesannya sistem sekolah, sejauh mana berkesannya seseorang guru dan lain-lain.

Mamat (1996) menyenaraikan lima tujuan penilaian iaitu; (i) menambah baik reka bentuk sesuatu program atau kurikulum pendidikan, (ii) mengenal pasti tahap pencapaian objektif sesuatu program atau kurikulum pendidikan, (iii) menambah baik kaedah pelaksanaan program atau kurikulum pendidikan, (iv) mempertingkatkan penguasaan pengetahuan dan kemahiran yang dipelajari oleh pelajar apabila memasuki alam pekerjaan dan (v) membantu sesebuah organisasi untuk membuat keputusan tentang pelaksanaa program dan kurikulum pendidikan serta pembangunan modal insan.

Scriven (1999) menyatakan penilaian formatif dilaksanakan bagi kurikulum atau program pendidikan yang masih dalam peringkat perancangan. Menurut beliau, hasil kajian dapat digunakan sebagai garis panduan dalam penambah baik sesuatu kurikulum atau program dalam membantu meningkatkan prestasi sesuatu kurikulum atau program. Beliau juga berpendapat bahawa hasil penilaian formatif diperlukan oleh pihak yang berkaitan seperti perancang program atau kurikulum pendidikan, pentadbir program atau kurikulum pendidikan, lembaga penyelia (oversight board) atau pembiaya kewangan bagi tujuan mengoptimumkan keberkesanan sesuatu program atau kurikulum pendidikan. Maklumat yang diperlukan oleh pihak tersebut di atas adalah berkenaan dengan keperluan sesuatu program atau kurikulum pendidikan, konsep serta reka bentuk program atau kurikulum pendidikan, pelaksanaan dan keberkesanannya. Manakala Rossi (2018) pula menjelaskan bahawa dalam reka bentuk penilaian formatif yang memberi maklum balas yang berfaedah kepada pengurus dan penaja program atau kurikulum pendidikan baharu biasanya memberi tumpuan pada peringkat proses atau pelaksanaan sesuatu program atau kurikulum. Tambah beliau lagi, bagi mengenal pasti sejauh manakah pelaksanaan sesuatu program atau kurikulum sesebuah organisasi yang sudah kukuh penilaian proses (pelaksanaan) dilakukan bagi mendapatkan maklumat seperti mutu perkhidmatannya atau kejayaannya mencapai sasaran seperti yang dirancang.

Keseluruhannya penilaian adalah bermatlamat untuk membantu individu dan organisasi dalam membuat penambah baik dalam aspek perancangan, dasar dan amalan individu dan sesebuah organisasi tersebut dalam melaksanakan sesuatu program. Selain itu, Wimbush \& Watson (2000) menjelaskan penilaian dilaksanakan dengan tujuan yang pelbagai mengikut situasi yang berbeza seperti menyokong sesuatu pendapat, mendapatkan maklumat berkaitan keberkesanaan sesuatu program atau kurikulum, menyediakan input bagi tujuan membuat keputusan berkaitan pembiayaan kewangan, struktur atau pentadbiran sesuatu program atau kurikulum pendidikan, maklum balas terhadap tekanan politik atau kombinasi beberapa tujuan tersebut.

\section{PENDEKATAN DAN MODEL PENILAIAN KURIKULUM}

Pendekatan merujuk kepada kaedah penilaian. Menurut Scriven (1999), menjelaskan kaedah penilaian dirujuk sebagai pendekatan atau model konsepsi yang diguna oleh penilai sebagai garis panduan dalam melaksanakan kajian penilaian. Hujah ini disokong oleh Darusalam (2003) yang menyatakan bahawa huraian perkataan biasanya dirujuk sebagai teori manakala lakaran gambar rajah dirujuk sebagai model bagi menjelaskan sesuatu kajian penilaian. Tambah beliau lagi, bagi menjelaskan sesuatu definisi, pendapat, konsep, ciri, prinsip, aliran atau teori dan model terdapat dua kaedah yang dikemukan oleh pengasasnya. Justeru itu, bagi menjelaskan perbezaan antara teori dan model sesuatu definisi, idea, konsep, prinsip, ciri, aliran serta kriteria teori dan model adalah dari segi bentuk iaitu teori dalam bentuk perkataan dan model dalam bentuk gambar rajah.

Zakaria, N. A. (2019). Penilaian Pelaksanaan Kurikulum Mata Pelajaran Sains Rumah Tangga Menggunakan Model Stake Countenance: Satu Kajian Literatur. Journal of Vocational Education Studies, 2(1), 37-46. DOI: https://doi.org/10.12928/joves.v2i1.647. 
Menurut Azizi \& rakan (2007) menyatakan aktiviti penilaian program pendidikan dapat dilaksanakan dengan lengkap dan bermakna dengan adanya sebuah model yang menjadi panduan sesuatu penilaian. Model adalah satu gambaran konseptual tentang sesuatu aktiviti yang dapat menunjukkan perkaitan antara berbagai elemen yang terlibat di dalam aktiviti tersebut. Terdapat empat pendekatan yang biasa digunakan dalam kajian penilaian kurikulum atau program pendidikan (Fitzpatrick et al., 2017; Stufflebeam, 2001; Stufflebeam \& Shinkfield, 2012).

Jadual 1. Jenis Pendekatan Penilaian dan Model Penilaian

\begin{tabular}{|c|c|c|c|}
\hline $\begin{array}{c}\text { Pendekatan } \\
\text { Berorientasikan } \\
\text { Objektif }\end{array}$ & $\begin{array}{l}\text { Pendekatan } \\
\text { Berorientasikan } \\
\text { Pengguna }\end{array}$ & $\begin{array}{c}\text { Pendekatan } \\
\text { Berorientasikan } \\
\text { Keputusan/ } \\
\text { Akauntabiliti }\end{array}$ & $\begin{array}{l}\text { Pendekatan } \\
\text { Berorientasikan } \\
\text { Pelanggan }\end{array}$ \\
\hline $\begin{array}{l}\text { Digunakan untuk } \\
\text { menentukan sama } \\
\text { ada objektif } \\
\text { program tercapai } \\
\text { atau tidak } \\
\text { (Stufflebeam, 2001) }\end{array}$ & $\begin{array}{l}\text { Memberi fokus } \\
\text { kepada } \\
\text { keberkesanan } \\
\text { produk dan } \\
\text { perkhidmatan } \\
\text { seperti buku teks, } \\
\text { bahan bantu } \\
\text { mengajar dan } \\
\text { sebagainya yang } \\
\text { memberi kepuasan } \\
\text { kepada pengguna } \\
\text { (Fitzpatrick et al., } \\
\text { 2017). }\end{array}$ & $\begin{array}{l}\text { Digunakan untuk } \\
\text { menilai program } \\
\text { pendidikan bagi } \\
\text { tujuan penambah } \\
\text { baik (Stufflebeam, } \\
\text { 2001) }\end{array}$ & $\begin{array}{l}\text { Menekankan } \\
\text { pengalaman } \\
\text { sebenar peserta } \\
\text { yang terlibat dalam } \\
\text { aktiviti harian } \\
\text { sesuatu kurikulum } \\
\text { (Stake, 1967). }\end{array}$ \\
\hline $\begin{array}{l}\text { Model Penilaian } \\
\text { Tyler (1949) } \\
\text { Model Penilaian } \\
\text { Diskrepensi Provus } \\
\text { (1969) } \\
\text { Model Penilaian } \\
\text { Metfessel dan } \\
\text { Michael (1967) } \\
\text { Model Penilaian } \\
\text { Logik (Logic Model) }\end{array}$ & $\begin{array}{l}\text { Model Penilaian } \\
\text { Goal Free } \\
\text { Evaluation (1974) }\end{array}$ & $\begin{array}{l}\text { Model Penilaian } \\
\text { CIPP (context, Input, } \\
\text { Process, Product) } \\
\text { Model Penilaian } \\
\text { UCLA (UCLA Model) } \\
\text { Model Penilaian The } \\
\text { Phi Delta Kappa } \\
\text { Committee (1969) }\end{array}$ & $\begin{array}{l}\text { Model Penilaian } \\
\text { Stake Countenance } \\
\text { Model Penilaian } \\
\text { Responsif } \\
\text { (Responsive } \text { Model) }\end{array}$ \\
\hline
\end{tabular}

Kepelbagaian jenis model penilaian program dan kurikulum biasa digunakan dalam kajian penilaian tetapi model penilaian program Stake's Countenance (1967) dijadikan sebagai garis panduan dan kerangka konsep kajian kerana model ini adalah model pendekatan berorientasikan pelanggan yang memberi dapatan sebenar semua peserta yang terlibat dalam sesuatu kurikulum serta bersesuaian untuk mencapai objektif dan tujuan kajian iaitu menilai pelaksanaan kurikulum mata pelajaran Sains Rumah Tangga. Ini kerana model penilaian ini membolehkan penyelidik membuat kajian pelaksanaan kurikulum secara menyeluruh dan sistematik yang menekan kepada aspek penambah baik sesuatu pelaksanaan kurikulum. Pelaksanaaan kurikulum mata pelajaran Sains Rumah Tangga melibatkan guru dan murid secara langsung. Justeru itu, Pendekatan berorientasikan pelanggan adalah bertepatan dengan tujuan penilaian.

Zakaria, N. A. (2019). Penilaian Pelaksanaan Kurikulum Mata Pelajaran Sains Rumah Tangga Menggunakan Model Stake Countenance: Satu Kajian Literatur. Journal of Vocational Education Studies, 2(1), 37-46. DOI: https://doi.org/10.12928/joves.v2i1.647. 


\section{MODEL PENILAIAN STAKE COUNTENANCE}

Model penilaian ini boleh digunakan dalam menilai kurikulum atau program pendidikan yang sedang dalam pelaksanaan untuk melihat proses perlaksanaan program tersebut. Menurut Thanabalan \& rakan (2015) proses penilaian yang dilaksankan secara sistematik meggunakan model penilaian Stake Countenance dapat mengukur objektif sebenar program dengan tepat dan bersesuaian dengan program yang sedang dalam pelaksanaan. Justeru itu, model Penilaian Stake Countenance merupakan model penilaian yang berguna untuk merancang kajian penilaian dalam menilai proses pelaksanaan kurikulum pendidikan seperti pembelajaran secara kompleks. Model ini diasas dan dikembangkan oleh Stake (1967). Perkataan countenance adalah dari perkataan bahasa Inggeris yang membawa maksud persetujuan atau menyetujui. Manakala secara ilmiah, istilah countenance membawa maksud penilaian yang memberi penumpuan kepada pelaksanaan matrik deskripsi dan matrik pertimbangan kurikulum atau program pendidikan yang dinilai. Menurut Stake (1967) model penilaiannya adalah berdasar kepada penilaian formal yang bergantung kepada senarai semak, lawatan berstruktur oleh rakan sepasukan, perbandingan dengan kumpulan kawalan penilaian dan piawaian ujian pelajar.

Worthen \& Sanders (1973) menyatakan model Penilaian Stake Countenance merupakan satu alat atau garis panduan yang berguna untuk merancang kajian penilaian. Stake (1967) mencadangkan dua tindakan utama dalam kajian penilaian formal iaitu matrik deskripsi dan matrik pertimbangan kurikulum atau program pendidikan yang dinilai. Mengikut Worthen \& Sanders (1973) dengan menggunakan kerangka Model Stake Countenance sebagai alat penilaian, penilai dapat; (i) mengemukakan latar belakang, justifikasi dan deskripsi rasional kurikulum atau program pendidikan (termasuk keperluan), (ii) menyenaraikan masukan (antecedents) iaitu tujuan atau rancangan yang diharapkan, proses (transactions) dan hasil pengajaran dan pembelajaran (outcomes), (iii) rekod pemerhatian aktiviti, transaksi dan hasil termasuk pemerhatian ciri yang tidak dijangka (observations of unintended features of each), (iv) piawaian (kriteria, harapan, perbandingan pencapaian kurikulum atau program) untuk membuat pertimbangan masukan, proses dan hasil sesuatu kurikulum atau program yang dinilai, dan (v) merekod pertimbangan tentang keadaan masukan, proses dan hasil.

Model Penilaian Stake Countenance terdiri daripada matrik deskripsi (descriptive matrix) dan matrik pertimbangan (judgment matrix). Matrik deskripsi mempunyai dua bahagian iaitu tujuan atau rancangan (intents) dan pemerhatian (observations). Manakala matrik pertimbangan mempunyai bahagian piawaian (standards) dan pertimbangan (judgments). Setiap matrik terdapat tiga fasa data iaitu masukan (antecedents), proses (transactions) dan hasil (outcomes). Menurut Worthen \& Sanders (1973) masukan adalah keadaan yang wujud dalam pengajaran dan pembelajaran yang mempengaruhi hasil pembelajaran, keadaan yang wujud sebelum pelaksanaan, keadaan sedia ada berkaitan dengan pengajaran dan pembelajaran yang berhubung dengan hasil pembelajaran. Untuk lebih jelas Model Stake Countenance ditunjukkan dalam Rajah 1.

Zakaria, N. A. (2019). Penilaian Pelaksanaan Kurikulum Mata Pelajaran Sains Rumah Tangga Menggunakan Model Stake Countenance: Satu Kajian Literatur. Journal of Vocational Education Studies, 2(1), 37-46. D0I: https://doi.org/10.12928/joves.v2i1.647. 


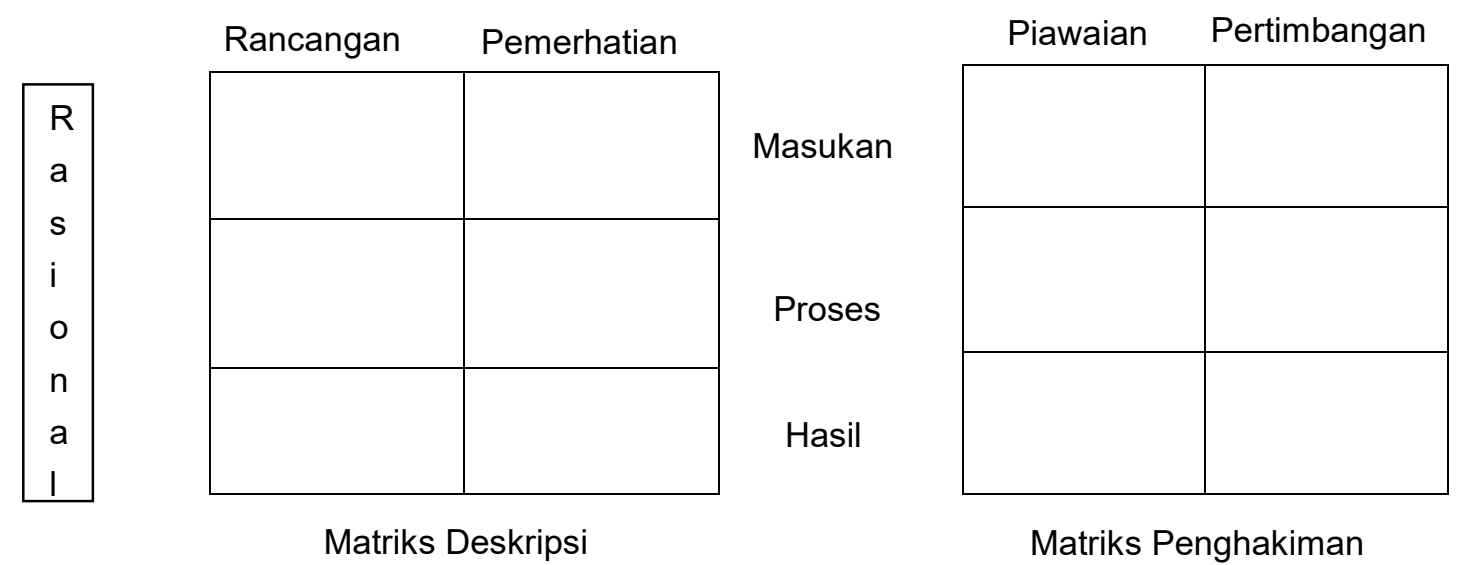

Rajah 1. Model Penilaian Stake Countenance (Stufflebeam \& Shinkfield, 2012)

Dalam Model Penilaian Stake Countenance ini, penilai bukan sahaja melaksanakan matrik deskripsi dan matrik pertimbangan tetapi juga melihat kepada contigency dan kesesuaian (congruence) dari data yang telah diperolehi. Contigency terdiri contigency logik dan contigency empirikal. Contigency logik adalah hasil pertimbangan penilai terhadap kesesuaian logik antara masukan dengan proses dan hasil. Ini adalah pertimbangan pertama yang harus dilakukan oleh penilai. Selanjutnya penilai pula, memberikan pertimbangan empirikal (empirical contigency) berdasarkan data yang diperoleh di tempat kajian, antara masukan, proses dan hasil. Selain mencari contigency, penilai kemudian memberikan pertimbangan mengenai congruence atau perbezaan yang berlaku antara apa yang dirancang pada awalnya bagi sesuatu program atau kurikulum dengan apa yang sebenarnya berlaku dalam kajian. Gambaran yang jelas berkenaan prosedur kerja penilaian menggunakan Model Penilaian Stake Countenance dapat dilihat dalam Rajah 2.

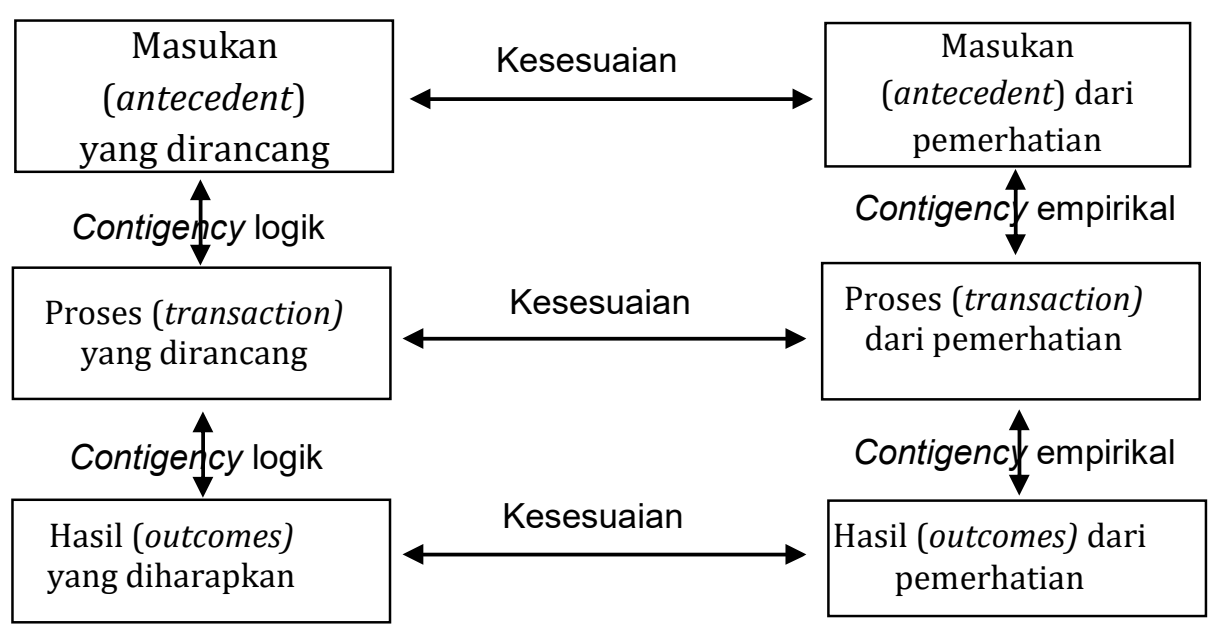

Rajah 2. Cara Kerja Model Penilaian Stake Countenance (Stufflebeam \& Shinkfield, 2012). 
Jadual 2. Kajian Lepas Luar dan Dalam Negara Menggunakan Model Penilaian Stake Countenance

\begin{tabular}{|c|c|c|c|}
\hline $\begin{array}{c}\text { Penyelidikan } \\
\text { dan Tahun }\end{array}$ & Negara & Bidang & Tujuan \\
\hline $\begin{array}{l}\text { Fatima dan } \\
\text { rakan } \\
(2016)\end{array}$ & $\begin{array}{l}\text { Punjab, } \\
\text { Pakistan }\end{array}$ & $\begin{array}{l}\text { Pendidikan } \\
\text { awal kanak- } \\
\text { kanak }\end{array}$ & $\begin{array}{l}\text { Menilai pencapaian pembacaan dan } \\
\text { penulisan Bahasa Inggeris dan Urdu } \\
\text { dalam kalangan kanak-kanak istimewa } \\
\text { masalah pendengaran }\end{array}$ \\
\hline $\begin{array}{l}\text { Deepwell } \\
(2002)\end{array}$ & $\begin{array}{l}\text { Coventry } \\
\text { Universiti, } \\
\text { United } \\
\text { Kingdom }\end{array}$ & $\begin{array}{l}\text { Pendidikan } \\
\text { teknologi } \\
\text { maklumat } \\
\text { dan } \\
\text { komputer } \\
\end{array}$ & $\begin{array}{l}\text { Penilaian terhadap pelaksanaan } \\
\text { persekitaran } \\
\text { pembelajaran maya (VLE) }\end{array}$ \\
\hline $\begin{array}{l}\text { Wood } \\
(2001)\end{array}$ & Virginia, USA & $\begin{array}{l}\text { Pendidikan } \\
\text { persekitaran }\end{array}$ & $\begin{array}{l}\text { Menerangkan kesesuaian (congruence) } \\
\text { antara apakah yang dirancang dan apakah } \\
\text { yang sebenarnya berlaku sebelum, } \\
\text { semasa dan selepas pengajaran } \\
\text { pendidikan persekitaran }\end{array}$ \\
\hline $\begin{array}{l}\text { Treagust \& } \\
\text { Rennie } \\
\text { (1993) }\end{array}$ & $\begin{array}{l}\text { Western } \\
\text { Australia }\end{array}$ & $\begin{array}{l}\text { Teknologi } \\
\text { Pendidikan }\end{array}$ & $\begin{array}{l}\text { Penggunaan teknologi dalam pelaksanaan } \\
\text { kurikulum pengajaran dan pencapaian } \\
\text { kurikulum berdasarkan kepada darjah } \\
\text { perbezaan antara tujuan dan pelaksanaan } \\
\text { sebenar kurikulum }\end{array}$ \\
\hline $\begin{array}{l}\text { Gondikit } \\
\text { (2018) }\end{array}$ & $\begin{array}{l}\text { Sabah, } \\
\text { Malaysia }\end{array}$ & $\begin{array}{l}\text { Pembelajaran } \\
\text { Pelajar }\end{array}$ & $\begin{array}{l}\text { Penilaian terhadap keupayaan belajar di } \\
\text { luar bilik darjah selepas Pentaksiran } \\
\text { Tingkatan Tiga (PT3) }\end{array}$ \\
\hline $\begin{array}{l}\text { Thanabalan } \\
\text { \& rakan } \\
(2015)\end{array}$ & $\begin{array}{l}\text { Semenanjung } \\
\text { Malaysia }\end{array}$ & $\begin{array}{l}\text { Teknologi } \\
\text { Pendidikan }\end{array}$ & $\begin{array}{l}\text { Mengkaji pelaksanaan penggunaan modul } \\
\text { literasi digital dalam kalangan pelajar } \\
\text { orang asli }\end{array}$ \\
\hline
\end{tabular}

\section{KESIMPULAN}

Pendidikan vokasional peringkat sekolah menengah memainkan peranan utama dalam membekalkan kemahiran asas pekerjaan dan pembangunan modal insan bagi sesebuah negara dan seterusnya pembangunan negara secara berkesan. Keberkesanan hasil pendidikan vokasional seperti mata pelajaran Sains Rumah Tangga bergantung kepada pelaksanaan kurikulum seperti yang dirancang. Menurut Fullan \& Pomfret (1977) kerjasama dan sekongan semua pihak merupakan faktor utama pelaksanaan sesuatu inovasi pendidikan selain ciri-ciri inovasi itu sendiri yang jelas matlamatnya.

Penentu kejayaan pelaksanaan sesuatu kurikulum pendidikan bergantung kepada guru yang dianggap sebagai pelaksana (Tamir, 1991). Pelaksana kurikulum, seperti guru selain murid memainkan peranan penting dalam pelaksanaan sesuatu kurikulum pendidikan. Justeru itu, guru harus dibekalkan dengan aktiviti pembangunan profesional dan sumber sokongan yang bersesuaian dan bertepatan bagi memastikan kejayaan pelaksanaan sesuatu kurikulum vokasional di sekolah. Maka, maklumat dan tujuan yang diperoleh melalui kajian penilaian kurikulum bukan hanya menjelaskan apa sebenarnya berlaku dalam sesuatu kurikulum namun juga mentaksir dan menerangkannya (Werner, 2004). 


\section{RUJUKAN}

Akta Pendidikan 1996 (akta 550). (1996). Retrieved from http://www.polisas.edu.my/portal/images/stories/Mqa/Akta550.pdf.

Cronbach, L. J. (1983). Course Improvement through Evaluation Evaluation Models: Viewpoints on Educational and Human Services Evaluation (pp. 101-115). Dordrecht: Springer Netherlands.

Darusalam, G. (2003). Keberkesanan kursus Pengajian Agama Islam, Diploma Perguruan Malaysia di Maktab-Maktab Perguruan Malaysia. (Tesis Ijazah Kedoktoran Falsafah yang tidak diterbitkan), Universiti Malaya.

Dokumen Standard Kurikulum dan Pentaksiran, Mata Pelajaran Sains Rumah Tangga Tingkatan 4. (2015). Putrajaya, Kuala Lumpur.

Eisner, E. W. (1967). Instructional and expressive educational objectives: Their formulation and use in curriculum.

Eisner, E. W. (1993). Reshaping assessment in education: Some criteria in search of practice. Journal of Curriculum Studies, 25(3), 219-233.

Fitzpatrick, J. L., Sanders, J. R., \& Worthen, B. R. (2017). Program Evaluation: Alternative Approaches and Practical Guidelines (4th ed.). Boston, MA: Pearson Education.

Fullan, M., \& Pomfret, A. (1977). Research on Curriculum and Instruction Implementation. Review of Educational Research, 47(2), 335-397. doi:10.3102/00346543047002335

Kassim, N. F., \& Jalal, F. H. A. (2015). Kurikulum pendidikan awal kanak-kanak dan Modul pendidikan akhlak: Isu dan cabaran masa kini. . Paper presented at the Seminar Penyelidikan Kebangsaan Universiti Pendidikan Sultan Idris, Universiti Pendidikan Sultan Idris.

Mamat, I. (1996). Reka bentuk dan pengurusan latihan: Konsep dan amalan. Kuala Lumpur: Dewan Bahasa dan Pustaka.

Metfessel, N. S., \& W.B., M. (1967). A paradigm involving multiple criterion measures for the evaluation of the effectiveness of school programs. Educational and Psychological Measurement, 27, 931-943.

Ornstein, A., \& Hunkins, F. . (2013). Curriculum: Foundations, principles, and issues (6th ed.). Boston, Mass: Allyn and Bacon.

Pekeliling Ikhtisas Kementerian Pendidikan Malaysia bilangan 9 Tahun 2016. Pelaksanaan Kurikulum Standard Sekolah Menengah secara berperingkat-peringkat mulai tahun 2017. (2016). Putrajaya, Kuala Lumpur.

Popham, W. J. (1993). Educational Evaluation. Boston, MA: Allyn and Bacon.

Rohana Hamzah, Z. O., Hasnah Hussiin, Zuraina Ali \& Nur Qistina Abdullah. (2017). Pembangunan model penilaian kurikulum berteraskan nilai universal bagi program pendidikan berteraskan teknologi \& kejuruteraan: Satu Kerangka konseptual. International Journal of Humanities Technology and Civilization, No.1, 50-61.

Rossi, P. H., Lipsey, M. W., \& Henry, G. T. (2018). Evaluation: A Systematic Approach (8th ed.). Thousand Oaks, California: SAGE Publications, Inc.

Scriven, M. (1999). The Fine Line Between Evaluation and Explanation. Research on Social Work Practice, 9(4), 521-524. doi:10.1177/104973159900900407

Stake, R. E. (1967). The countenance of educational evaluation: Citeseer.

Stake, R. E. (1983). Program evaluation, particularly responsive evaluation Evaluation models (pp. 287-310): Springer.

Stufflebeam, D. (2001). Evaluation models. New directions for evaluation, 2001(89), 7-98.

Stufflebeam, D., \& Shinkfield, A. J. (2012). Systematic evaluation: A self-instructional guide to theory and practice (Vol. 8): Springer Science \& Business Media.

Zakaria, N. A. (2019). Penilaian Pelaksanaan Kurikulum Mata Pelajaran Sains Rumah Tangga Menggunakan Model Stake Countenance: Satu Kajian Literatur. Journal of Vocational Education Studies, 2(1), 37-46. DOI: https://doi.org/10.12928/joves.v2i1.647. 
Stufflebeam, D. L. (1971). The relevance of the CIPP evaluation model for educational accountability.

Tabori, J. R., \& Hermann, J. A. (2001). Project Planning and Evaluation Guidebook: A Manual for Practitioners and Managers of Self Sufficiency Demonstration Projects. Washington DC: Sosiological Practice Association.

Tamir, L. (1991). Profesional and personal knowledge of teachers and teacher educator. Teaching and Teacher Education, 7(3), 263-268.

Thanabalan, T. V., Siraj, S., \& Alias, N. (2015). Evaluation of a digital story pedagogical module for the indigenous learners using the Stake Countanance model. The Turkish Online Journal of Educational Technology, 2.

Tyler, R. W. (1942). General Statement on Evaluation. The Journal of Educational Research, 35(7), 492-501. doi:10.1080/00220671.1942.10881106

Tyler, R. W. (1949). Basic principles of curriculum and instruction Basic principles of curriculum and instruction. Chicago: The University of Chicago Press.

Werner, A. (2004). A guide to implementation research. Washington, DC: The Urban Institute Press.

Wholey, J. S. (2010). Handbook of Practical Program Evaluation San Fransisco: Jossey-Bass.

Wimbush, E., \& Watson, J. (2000). An evaluation framework for health promotion: theory, quality and effectiveness. Evaluation, 6(3), 301-321.

Worthen, B.R., \& Sanders,J.R. (1973). Educational evaluation: theory and practice. . United States of America: Wadsworth Publishing Company.

Yahaya, A. (2001). The using of model context, input, process and products (CIPP) in learning programs assessment. Paper presented at the Paper presented at the International Conference on Challenges and Prospects in Teacher Education, Universiti Teknologi Malaysia, Skudai.

Yahaya Azizi, Y. N., Hashim Shahrin \& Ramli Jamaluddin. (2007). Sejauh manakah model Stufflebeam (KIPP) boleh membantu dalam penilaian program pembelajaran?.Retrieved from http://eprints.utm.my/id/eprint/2256/.

Zakaria, N. A. (2019). Penilaian Pelaksanaan Kurikulum Mata Pelajaran Sains Rumah Tangga Menggunakan Model Stake Countenance: Satu Kajian Literatur. Journal of Vocational Education Studies, 2(1), 37-46. DOI: https://doi.org/10.12928/joves.v2i1.647. 